\title{
Fungicide resistance of Botrytis cinerea from strawberry to procymidone and zoxamide in Hubei, China
}

\author{
Muhammad Adnan ${ }^{1}$, Mohamed Sobhy Hamada ${ }^{1,2}$, Matthias Hahn ${ }^{3}$ Guo-Qing Li ${ }^{4}$ and Chao-Xi Luo ${ }^{1,4^{*}}$ (D)
}

\begin{abstract}
Gray mold, caused by Botrytis cinerea, is one of the most destructive diseases of strawberry in China. For resistance monitoring, 198 B. cinerea isolates were collected from strawberry greenhouses at 10 locations in Hubei Province. The isolates were screened for resistance to fungicides procymidone and zoxamide. In mycelium growth assays for procymidone, the mean values of effective concentration at which mycelium growth is inhibited by $50 \%$ (EC $C_{50}$ ) for sensitive $\left(\right.$ Pro $^{S}$ ) and resistant $\left(\right.$ Pro $^{R}$ ) isolates were $0.25 \mu \mathrm{g} / \mathrm{mL}$ and $2.21 \mu \mathrm{g} / \mathrm{mL}$, respectively. The frequency of Pro ${ }^{R}$ isolates was 14\%, and the highest frequency (48\%) was observed in Yichang. Positive cross-resistance was detected for $\operatorname{Pro}^{R}$ isolates to other dicarboximide fungicides, but not to phenylpyrroles. Comparative analysis of fitness parameters revealed increased osmotic sensitivity of $\operatorname{Pro}^{R}$ isolates compared to Pro ${ }^{S}$ ones. Sequence analysis of the dicarboximide target gene $B c O s 1$ revealed that Pro $^{\mathrm{R}}$ isolates carried either a single point mutation at codon 365 (1365S) or a pair of point mutations (Q369P and N373S). The mean $\mathrm{EC}_{50}$ values for zoxamide sensitive (Zox ${ }^{\mathrm{S}}$ ) and resistant $\left(Z o x^{R}\right)$ isolates were $0.31 \mu \mathrm{g} / \mathrm{mL}$ and $7.76 \mu \mathrm{g} / \mathrm{mL}$, respectively. Only six (3\%) isolates from three locations were found to be resistant to zoxamide. All Zox ${ }^{R}$ isolates were found resistant to carbendazim. Fitness parameters did not show significant difference between $\mathrm{Zox}^{\mathrm{R}}$ and $\mathrm{Zox}^{\mathrm{S}}$ isolates. Sequence analysis of the beta-tubulin gene in resistant isolates revealed four previously reported point mutations (E198A, E198K, F200Y and T351I). The mutation T351I was detected only in the isolates possessing E198K point mutation. Mutation F200Y was detected in a highly resistant isolate. Results of this study will be helpful for the management of fungicide resistance in $B$. cinerea.
\end{abstract}

Keywords: Botrytis cinerea, Fungicide resistance, Dicarboximide, Benzamide, Strawberry

\section{Background}

Gray mold of strawberries, caused by Botrytis cinerea Pers. is considered one of the most destructive diseases threatening strawberry production, especially in greenhouses not only in Hubei Province but also worldwide. B. cinerea can cause up to $50 \%$ pre-harvest losses under suitable environmental condition and may reach to $90 \%$ under severe conditions (Ellis and Grove 1982). The ability to adapt to different environmental conditions and the massive production of conidia has made this

\footnotetext{
*Correspondence: cxluo@mail.hzau.edu.cn

'Key Lab of Horticultural Plant Biology, Ministry of Education, and College of Plant Science and Technology, Huazhong Agricultural University, Wuhan 430070, China

${ }^{4}$ College of Plant Science and Technology and the Key Lab of Crop Disease Monitoring \& Safety Control in Hubei Province, Huazhong Agricultural University, Wuhan 430070, China

Full list of author information is available at the end of the article
}

fungus very destructive and at high risk for resistance development (Braun and Sutton 1987; Diolez et al. 1995; Leroux et al. 2002; Brent and Hollomon 2007; Williamson et al. 2007; Xiang et al. 2015). Application of agrochemicals has been considered as the most efficient way to control B. cinerea. More than half a billion dollar worth of fungicides are sprayed annually (Dean et al. 2012). Various groups of fungicides including benzimidazoles (MBCs), N-phenylcarbamates (NPCs), dicarboximides (DCFs), anilinopyrimidines (APs), quinone outside inhibitors (QoIs), succinate dehydrogenase inhibitors (SDHIs), and phenylpyrroles (PPs) are mostly used to control B. cinerea. However, their efficacy has markedly decreased by the emergence of resistant isolates. Despite weekly spray of fungicides, pre-harvest losses caused by B. cinerea may still reach to $15 \%$ of the total production (Legard and Chandler 1998). 
DCFs are cyclic imides (e.g. procymidone, iprodione) inhibiting both mycelium growth and conidial germination by interfering with osmoregulation (Elad et al. 2004). In the late 1970s, DCFs replaced MBCs for the management of B. cinerea (Elad et al. 2004). Excessive use of DCFs to control $B$. cinerea has resulted in resistance selection and reduced their efficacy worldwide (Faretra and Pollastro 1991; Elad et al. 1992; Moorman and Lease 1992; Pappas 1997; Leroux et al. 1999). Various mutations in the Botrytis cinerea two-component histidine kinase gene $(B c O s 1)$ responsible for resistance to DCFs have been identified in $B$. cinerea populations from different countries. Among various resistance genotypes, substitutions at codon I365 were predominant (Neumann 1992; Oshima et al. 2006; Ma et al. 2007). In procymidone resistant isolates, mutation of glutanine to proline at codon 369 (Q369P) was always found to be paired with the mutation of asparagine to serine at codon 373 (N373S) (Liu et al. 2016). Similarly, moderate resistant (MR) phenotypes were reported to be related to a combination of two mutations, e.g., Q369P and N373S, but mutations of isoleucine to asparagine/serine at condon 365 (I365N/S) were associated with low resistant (LR) phenotype (Grabke 2014).

Zoxamide is not only an oomycete fungicide but also has good activity against true fungi including $B$. cinerea (Young and Slawecki 2001; Cai et al. 2016). It belongs to the benzamide group of fungicides, but has a similar mode of action as MBCs, which inhibits tubulin polymerization and arrests nuclear division of the pathogen by binding to $\beta$-subunit of microtubules (Young and Slawecki 2001). For decades, MBCs such as carbendazim have been used to control B. cinerea (Malathrakis 1979; Smith 1988), and resistance against MBCs has been selected soon after they were introduced. Various $B$. cinerea populations from all over the world have been reported as resistant to MBCs (Stehmann and Waard 1996). Several substitutions of $\beta$-tubulin have been reported to be responsible for resistance to MBCs in numerous pathogens including $B$. cinerea (Orbach et al. 1986; Fujimura et al. 1992; Dehne et al. 2004). Mutations at codons 198 and 200 are commonly reported (Malandrakis et al. 2011), and F200Y was also found responsible for high resistant (HR) phenotypes (Yarden and Katan 1993; Davidse and Ishii 1995). However, the situation was different for zoxamide (Young et al. 2001; Bi et al. 2011; Malandrakis et al. 2011; Bi et al. 2014). Compared to the high frequency of MBCs resistant isolates, the frequency of Zox ${ }^{\mathrm{R}}$ isolates was low, which might be because the two fungicides are binding to different target sites of $\beta$-tubulin (Cai et al. 2015).

Procymidone has been widely used in Hubei Province for many years but zoxamide was just introduced recently. The resistance situation of $B$. cinerea isolates from strawberries in Hubei Province was evaluated in this study. The primary objectives of the study are: (i) to determine the resistance frequency of $B$. cinerea isolates to procymidone, and zoxamide; (ii) to identify and evaluate the point mutations in the BcOs1 and BctubA gene; (iii) to suggest resistance management strategies.

\section{Results}

\section{Frequency of $B$. cinerea resistant isolates}

Monitoring of fungicide resistance among 198 isolates from strawberry in Hubei Province was conducted based on the determination of discriminatory doses of procymidone and zoxamide. Results showed that $14 \%$ (27 isolates) and 3\% (6 isolates) of tested isolates were resistant to procymidone and zoxamide, respectively. Isolates from Yichang showed the highest resistance frequencies (i.e., $48 \%$ and $67 \%$ ) to procymidone and zoxamide, respectively. No resistance was detected to procymidone in Shiyan, Xiangyang, Suizhou, Ezhou, Qianjiang and to zoxamide in most of the locations, except in Shiyan, Yichang, and Xiantao (Fig. 1a, b).

\section{Sensitivity of $B$. cinerea to procymidone and zoxamide}

The sensitivity of resistant and sensitive strawberry isolates was determined using mycelium growth assay to estimate the $\mathrm{EC}_{50}$ values of fungicides. The $\mathrm{EC}_{50}$ values of procymidone and zoxamide to sensitive isolates ranged from 0.14 to $0.33 \mu \mathrm{g} / \mathrm{mL}$ with a mean of $0.25 \mu \mathrm{g} /$ $\mathrm{mL}$ and from 0.14 to $0.39 \mu \mathrm{g} / \mathrm{mL}$ with a mean of $0.31 \mu \mathrm{g} / \mathrm{mL}$ (Fig. 2). The $\mathrm{EC}_{50}$ values for 27 procymidone resistant $\left(\right.$ Pro $^{\mathrm{R}}$ ) isolates ranged from 0.9 to $4.05 \mu \mathrm{g} / \mathrm{mL}$, with a mean of $2.21 \mu \mathrm{g} / \mathrm{mL}$. The $\mathrm{EC}_{50}$ values for the six zoxamide resistant $\left(\mathrm{Zox}^{\mathrm{R}}\right)$ isolates ranged from 4.32 to $20.25 \mu \mathrm{g} / \mathrm{mL}$, with a mean of $7.76 \mu \mathrm{g} / \mathrm{mL}$. Pro ${ }^{\mathrm{R}}$ and $\mathrm{Zox}^{\mathrm{R}}$ isolates exhibited a wide range of resistance levels with RF values ranging from 3.5 to 16 with a mean of 8.7, and from 14 to 65.5 with a mean of 25.14 , respectively (Table 1). Among $27 \mathrm{Pro}^{\mathrm{R}}$ isolates, 17 isolates were low resistant (LR), ten isolates were moderate resistant (MR) and no high resistant (HR) isolates were detected.

\section{Cross-resistance}

The sensitivity of Pro ${ }^{R}$ and Zox $^{R}$ isolates to other fungicides was determined using a discriminatory dose test. All Pro $^{\mathrm{R}}$ isolates showed positive cross-resistance to other DCFs (i.e., dimethachlon and iprodione), but were sensitive to the PP fungicide fludioxonil. In the case of $\mathrm{Zox}^{\mathrm{R}}$ isolates, positive cross-resistance to the MBC fungicide carbendazim was observed (Table 1).

\section{Resistance stability}

After 10 successive transfers and incubations on fungicide-free PDA, EC 50 values of $\mathrm{Pro}^{\mathrm{R}}$ and $\mathrm{Zox}^{\mathrm{R}}$ isolates were compared between the first and 10th 


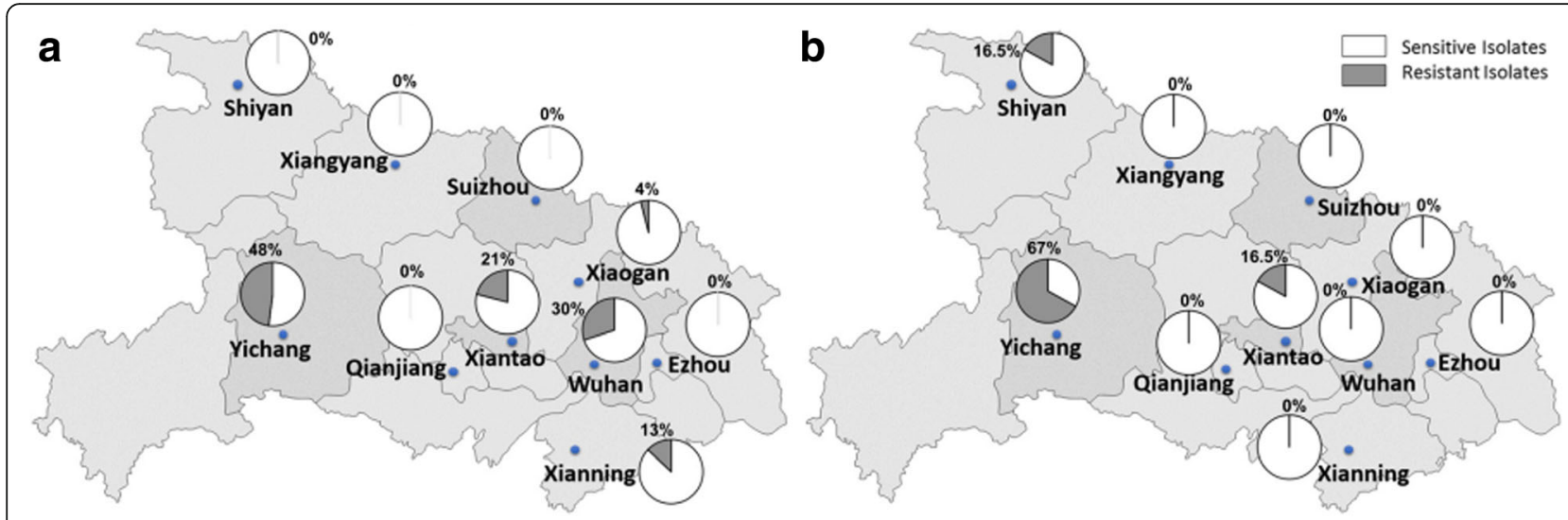

Fig. 1 Frequency distribution of procymidone (a) and zoxamide (b) resistant isolates of Botrytis cinerea collected from strawberry greenhouses in ten locations of Hubei Province, China

generation. The majority of isolates maintained similar levels of $\mathrm{EC}_{50}$ values. The variation in $\mathrm{EC}_{50}$ values was not significantly different $(P>0.05)$. Some isolates showed decreased resistance while others showed increased resistance, but collectively the isolates retained similar levels of resistance (Table 2), indicating that the resistances to procymidone and zoxamide were stable in B. cinerea.

\section{Fitness of resistant isolates}

Biological fitness parameters including mycelium growth, osmotic sensitivity, virulence, and sporulation were analyzed in selected $\operatorname{Pro}^{\mathrm{R}}$ and $\mathrm{Zox}^{\mathrm{R}}$ isolates, with some sensitive isolates as control. No significant differences in mycelium growth, virulence and sporulation, whereas significant differences $(P<0.05)$ in osmotic sensitivity were observed between $\operatorname{Pro}^{\mathrm{S}}$ and $\operatorname{Pro}^{\mathrm{R}}$ isolates

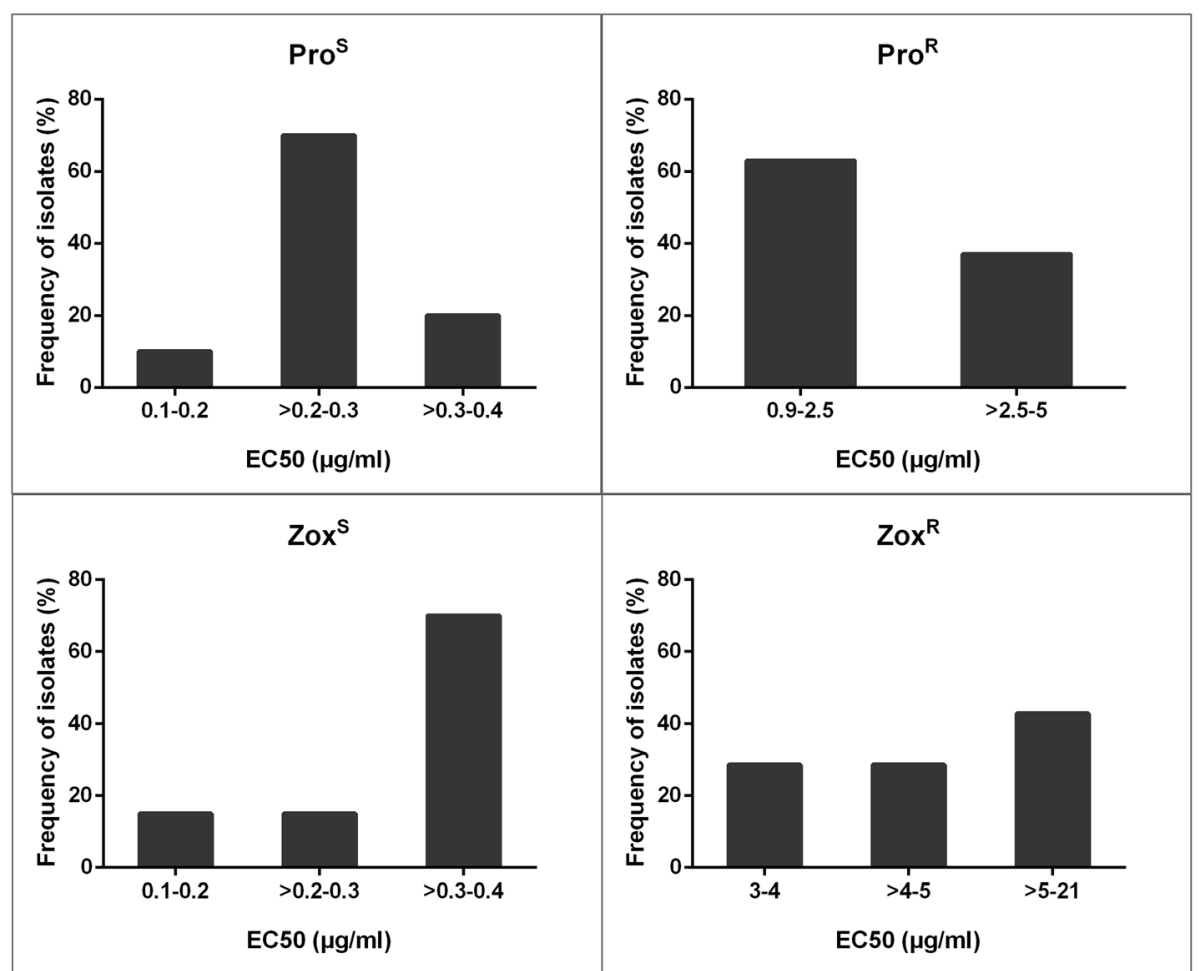

Fig. 2 Frequency distribution of $\mathrm{EC}_{50}$ values $(\mu \mathrm{g} / \mathrm{mL})$ for procymidone and zoxamide sensitive and resistant isolates of Botrytis cinerea collected from strawberry greenhouses in ten locations of Hubei Province, China. Pro ${ }^{S}$ and Pro $^{R}$ represent procymidone sensitive and resistant isolates, while Zox ${ }^{S}$ and Zox ${ }^{R}$ represent zoxamide sensitive and resistant isolates, respectively 
Table 1 Sensitivity of Botrytis cinerea sensitive and resistant isolates from strawberry to different fungicides

\begin{tabular}{|c|c|c|c|c|c|c|c|c|}
\hline \multirow[t]{2}{*}{ Phenotype } & \multirow[t]{2}{*}{ Isolate } & \multirow{2}{*}{$\begin{array}{l}\text { Resistance } \\
\text { levels }^{a}\end{array}$} & \multirow{2}{*}{$\begin{array}{l}\mathrm{EC}_{50} \\
(\mu \mathrm{g} / \mathrm{mL})^{\mathrm{b}}\end{array}$} & \multirow{2}{*}{$\begin{array}{l}\text { RF } \\
\text { value }^{c}\end{array}$} & \multicolumn{4}{|l|}{ Sensitivity $^{d}$} \\
\hline & & & & & Carbendazim $^{\mathrm{e}}$ & Dimethachlon $^{f}$ & Iprodione $^{f}$ & Fludioxonil $^{f}$ \\
\hline $\operatorname{Pro}^{\mathrm{S}}$ & S191 & S & 0.20 & - & - & S & S & S \\
\hline $\operatorname{Pro}^{\mathrm{S}}$ & S377 & S & 0.21 & - & - & S & S & S \\
\hline $\operatorname{Pro}^{\mathrm{S}}$ & S524 & S & 0.24 & - & - & S & S & S \\
\hline $\operatorname{Pro}^{\mathrm{S}}$ & S572 & S & 0.26 & - & - & S & S & s \\
\hline Pro $^{R}$ & S106 & LR & 1.52 & 6.02 & - & $R$ & $\mathrm{R}$ & S \\
\hline $\operatorname{Pro}^{R}$ & S111 & $L R$ & 2.45 & 9.70 & - & R & $\mathrm{R}$ & $\mathrm{S}$ \\
\hline $\operatorname{Pro}^{R}$ & WH36 & LR & 1.56 & 6.20 & - & R & $\mathrm{R}$ & $S$ \\
\hline $\operatorname{Pro}^{R}$ & YD4 & $L R$ & 1.64 & 6.50 & - & $R$ & $\mathrm{R}$ & S \\
\hline $\operatorname{Pro}^{R}$ & S151 & $\mathrm{MR}$ & 3.48 & 13.76 & - & $\mathrm{R}$ & $\mathrm{R}$ & $\mathrm{S}$ \\
\hline $\operatorname{Pro}^{R}$ & S155 & $\mathrm{MR}$ & 4.05 & 16.01 & - & $R$ & $\mathrm{R}$ & $\mathrm{S}$ \\
\hline $\operatorname{Pro}^{R}$ & S299 & $M R$ & 3.86 & 15.27 & - & R & $\mathrm{R}$ & $S$ \\
\hline $\operatorname{Pro}^{R}$ & YD3 & $\mathrm{MR}$ & 3.61 & 14.27 & - & R & $\mathrm{R}$ & S \\
\hline Zox ${ }^{\mathrm{s}}$ & S104 & S & 0.19 & - & $\mathrm{S}$ & - & - & - \\
\hline Zox & S295 & R & 4.32 & 13.99 & $R$ & - & - & - \\
\hline Zox ${ }^{R}$ & S329 & $\mathrm{R}$ & 4.53 & 14.68 & $\mathrm{R}$ & - & - & - \\
\hline Zox ${ }^{R}$ & S196 & $\mathrm{R}$ & 20.25 & 65.56 & $\mathrm{R}$ & - & - & - \\
\hline Zox $x^{R}$ & S133 & R & 4.83 & 15.66 & $\mathrm{R}$ & - & - & - \\
\hline Zox & S155 & $R$ & 6.73 & 21.80 & $\mathrm{R}$ & - & - & - \\
\hline Zox ${ }^{R}$ & S298 & $\mathrm{R}$ & 5.95 & 19.28 & $\mathrm{R}$ & - & - & - \\
\hline
\end{tabular}

${ }^{\mathrm{a}}$ Resistance levels of procymidone resistant isolates from strawberry. $\mathrm{LR}$ and $\mathrm{MR}$ represent low and moderate resistance, respectively; ${ }^{\mathrm{b}} \mathrm{EC} \mathrm{C}_{50}=\mathrm{fungicide}$ concentration resulting in inhibition of $50 \%$ mycelium growth rate; ${ }^{\mathrm{C}} \mathrm{RF}=$ Resistance Factor, it was calculated by dividing the $\mathrm{EC}_{50}$ value of the resistant isolate by the mean $\mathrm{EC}_{50}$ value of the sensitive isolates; ${ }^{\mathrm{d}} \mathrm{S}=\mathrm{Sensitive,} \mathrm{R}=$ Resistant. Discriminatory dose (a concentration of fungicide that fully inhibits mycelium growth of the sensitive isolates) used for sensitivity was $10,5,5$, or $1(\mu \mathrm{g} / \mathrm{mL})$ for carbendazim, dimethachlon, iprodione, or fludioxonil, respectively; ${ }^{e}$ Sensitivity of carbendazim to Zox ${ }^{R}$ isolates; ${ }^{f}$ Sensitivity of dimethachlon, fludioxonil and iprodione to Pro ${ }^{R}$ isolates

(Table 2). Zox ${ }^{\mathrm{R}}$ isolates did not show significant differences from $\mathrm{Zox}^{\mathrm{S}}$ isolates in these parameters except for sporulation. The osmotic sensitivity test demonstrated that Pro $^{\mathrm{R}}$ isolates showed reduced radial mycelium growth than Pro $^{\mathrm{S}}$ isolates on PDA amended with $8 \%$ $\mathrm{NaCl}$ (Table 2). Pro $^{\mathrm{R}}$ isolates were comparatively more sensitive to osmotic stress than Pro $^{\mathrm{S}}$ isolates (Table 2). Among Pro $^{R}$ isolates, YD4 displayed the highest growth inhibition by $\mathrm{NaCl}$. Virulence of the isolates was also evaluated by inoculation tests on strawberry leaves. No significant differences in mean lesion sizes were observed between resistant and sensitive isolates $(P>0.05)$. Similarly, no significant difference in virulence was detected between isolates with different levels of resistance (LR, MR) $(P>0.05)$. As for sporulation, no significant differences $(P>0.05)$ were found between Pro $^{R}$ and Pro $^{S}$ isolates, but Zox ${ }^{R}$ isolates showed significantly increased sporulation compared to sensitive ones $(P<0.05)$ (Table 2$)$.

\section{Fungicide efficacy}

In vivo fungicide sensitivity was assayed on detached strawberry leaves to evaluate the control efficacy of procymidone and zoxamide against $B$. cinerea isolates. The sensitive isolates were inhibited completely by the two fungicides as they failed to cause lesions on leaves. The control efficacy for Pro ${ }^{\mathrm{R}}$ isolates was observed to be only between $11.6 \%-24.4 \%$. In the case of $\mathrm{Zox}^{\mathrm{R}}$ isolates, the highest control efficacy detected was $22.5 \%$ for the isolate S155 (Table 2). The results demonstrated that there was a significant difference $(P<0.001)$ in control efficacy between sensitive and resistant isolates for both fungicides. The tested fungicides failed to control the resistant isolates at the recommended doses, which demonstrates the difficulty for the management of $B$. cinerea resistant isolates in practice.

\section{Molecular characterization of $B c O s 1$ and $B c t u b A$ gene}

The BcOs1 gene from one $S$, four LR, and four MR isolates to procymidone was sequenced. Isolates with different resistance phenotypes revealed several mutations. The resistant isolates (LR) revealed a point mutation at codon 365 from ATC to AGC resulting in the substitution of isoleucine to serine (I365S). A pair of point mutations was identified in the sequence of seven resistant isolates (3LR, 4MR). The first point mutation was detected at codon 369 from CAG to CCG, and the second was observed at codon 373 from AAC to AGC, resulting in replacement of glutamine to proline (Q369P) and asparagine to serine (N373S), respectively. A specific 
Table 2 Fitness components, control efficacy and stability of Botrytis cinerea isolates from strawberry

\begin{tabular}{|c|c|c|c|c|c|c|c|c|c|}
\hline \multirow[t]{2}{*}{ Phenotype } & \multirow[t]{2}{*}{ Isolate } & \multirow[t]{2}{*}{$\begin{array}{l}\text { Resistance } \\
\text { levels }^{\mathrm{a}}\end{array}$} & \multirow[t]{2}{*}{$\begin{array}{l}\text { Mycelium } \\
\text { growth }^{\text {b }}\end{array}$} & \multirow[t]{2}{*}{$\begin{array}{l}\text { Osmotic sensitivity } \\
8 \%(\mathrm{PIMG})^{c}\end{array}$} & \multirow[t]{2}{*}{$\begin{array}{l}\text { Virulence } \\
(\mathrm{cm})^{d}\end{array}$} & \multirow[t]{2}{*}{$\begin{array}{l}\text { Sporulation } \\
\left(\times 10^{6} / \mathrm{cm}^{2}\right)^{\mathrm{e}}\end{array}$} & \multirow[t]{2}{*}{$\begin{array}{l}\text { Control } \\
\text { efficacy }\end{array}$} & \multicolumn{2}{|c|}{$\begin{array}{l}\text { Resistance stability } \\
\text { EC50 }(\mu \mathrm{g} / \mathrm{mL})^{\mathrm{g}}\end{array}$} \\
\hline & & & & & & & & $1 s t$ & 10th \\
\hline Pro $^{5}$ & S191 & $S$ & 6.57 & 90.84 & 2.20 & 4.8 & 100 & - & - \\
\hline $\operatorname{Pro}^{\mathrm{S}}$ & S377 & $S$ & 6.57 & 97.85 & 2.23 & 4.0 & 100 & - & - \\
\hline $\operatorname{Pro}^{\mathrm{S}}$ & S524 & $S$ & 6.28 & 95.23 & 2.60 & 2.5 & 100 & - & - \\
\hline \multirow[t]{2}{*}{ Pro $^{\mathrm{S}}$} & S572 & $S$ & 6.26 & 95.21 & 2.45 & 2.1 & 100 & - & - \\
\hline & Mean & & $6.42 \mathrm{~A}$ & $94.78 \mathrm{~B}$ & $2.37 \mathrm{~A}$ & $3.36 \mathrm{~A}$ & $100 \mathrm{~A}$ & - & - \\
\hline Pro $^{R}$ & $\mathrm{~S} 106$ & LR & 5.61 & 104.66 & 2.62 & 6.2 & 23.37 & 1.52 & 2.176 \\
\hline Pro $^{R}$ & S111 & $L R$ & 5.98 & 101.61 & 2.39 & 3.2 & 11.56 & 2.45 & 2.799 \\
\hline $\operatorname{Pro}^{R}$ & WH36 & $L R$ & 6.68 & 107.85 & 2.23 & 5.4 & 16.28 & 1.56 & 2.397 \\
\hline \multirow[t]{2}{*}{$\operatorname{Pro}^{R}$} & YD4 & $L R$ & 4.59 & 110.49 & 2.35 & 3.2 & 24.36 & 1.64 & 3.338 \\
\hline & Mean & & $5.72 \mathrm{~A}$ & 106.15A & $2.4 \mathrm{~A}$ & $4.52 \mathrm{~A}$ & $18.89 \mathrm{~B}$ & $1.79 \mathrm{~A}$ & $2.67 \mathrm{~A}$ \\
\hline $\operatorname{Pro}^{R}$ & S151 & MR & 6.46 & 102.29 & 2.33 & 4.3 & 12.52 & 3.48 & 4.511 \\
\hline $\operatorname{Pro}^{R}$ & S155 & $\mathrm{MR}$ & 6.68 & 103.02 & 2.54 & 6.3 & 21.05 & 4.05 & 5.999 \\
\hline Pro $^{R}$ & S299 & MR & 6.26 & 106.78 & 2.40 & 2.2 & 23.13 & 3.86 & 2.779 \\
\hline \multirow[t]{2}{*}{$\operatorname{Pro}^{R}$} & YD3 & MR & 7.16 & 103.08 & 2.61 & 7.6 & 18.95 & 3.61 & 6.437 \\
\hline & Mean & & $6.64 \mathrm{~A}$ & 103.79A & $2.47 \mathrm{~A}$ & $5.11 \mathrm{~A}$ & $18.91 \mathrm{~B}$ & $3.75 \mathrm{~A}$ & $4.93 \mathrm{~A}$ \\
\hline Zox ${ }^{5}$ & S104 & $S$ & $7.12 \mathrm{~A}$ & - & $2.98 \mathrm{~A}$ & $3.83 B$ & $100 \mathrm{~A}$ & - & - \\
\hline Zox ${ }^{R}$ & S295 & $\mathrm{R}$ & 6.43 & - & 2.91 & 6.4 & 7.12 & 4.32 & 4.72 \\
\hline Zox ${ }^{R}$ & S329 & $\mathrm{R}$ & 6.74 & - & 2.01 & 7.2 & 20.29 & 4.53 & 4.41 \\
\hline Zox & S196 & $\mathrm{R}$ & 6.30 & - & 2.38 & 7.0 & 13.98 & 20.25 & 19.22 \\
\hline Zox ${ }^{R}$ & S133 & $\mathrm{R}$ & 7.08 & - & 3.54 & 6.8 & 11.01 & 4.83 & 4.59 \\
\hline Zox & S155 & $\mathrm{R}$ & 7.16 & - & 2.84 & 5.0 & 22.45 & 6.73 & 6.87 \\
\hline \multirow[t]{2}{*}{ Zox } & S298 & $\mathrm{R}$ & 7.33 & - & 2.1 & 5.4 & 18.22 & 5.95 & 6.11 \\
\hline & Mean & & $6.84 \mathrm{~A}$ & - & $2.64 \mathrm{~A}$ & $6.38 \mathrm{~A}$ & $15.51 \mathrm{~B}$ & $7.76 \mathrm{~A}$ & $7.65 \mathrm{~A}$ \\
\hline
\end{tabular}

${ }^{\mathrm{a}}$ Resistance levels of procymidone resistant isolates. LR and MR represent low and moderate resistance, respectively; ${ }^{\mathrm{b}} \mathrm{Mycelium}$ growth was measured as colony diameter $(\mathrm{cm})$ at $60 \mathrm{~h}$ under $23^{\circ} \mathrm{C} ;{ }^{\mathrm{C}}$ The percentage of inhibition of mycelial growth (PIMG) was calculated using the formula PIMG $=[(\mathrm{C}-\mathrm{N}) /(\mathrm{C}-5)] \times 100$, where $\mathrm{C}$ is the colony diameter of the non-treatment control, and $\mathrm{N}$ is that of the sodium chloride treatment; ${ }^{\mathrm{d}}$ Virulence was shown as the diameter of lesion size (cm) at 3 days under $23^{\circ} \mathrm{C} ;{ }^{e}$ Mean number $\left(\times 10^{6}\right)$ of conidia per square centimeter; ${ }^{f}$ Control efficacy was expressed as the percentage of the mean diameter of the control minus the mean diameter of the treatment divided by the mean diameter of the control; ${ }^{9}$ Stability of procymidone/zoxamide resistant isolates after 10 consecutive transfers on fungicide free medium ( $1^{\text {st }}$ and $10^{\text {th }}$ transfer), means were compared between $1^{\text {st }}$ and $10^{\text {th }}$ transfers of each group. Means indicate the sensitive and corresponding resistant groups, values within a column followed by the same letter are not significantly different according to $L S D$ test $(P=0.05)$

fragment of the $B c O s 1$ gene was amplified with a primer pair (Bc365PM-F + Bc365PM-R) from twelve additional resistant isolates. Among these isolates, the I365S point mutation was detected in four $\operatorname{Pro}^{\mathrm{R}}$ isolates, the I365N mutation in one isolate, and the paired point mutation (Q369P, N373S) in the remaining seven Pro $^{\mathrm{R}}$ isolates.

The $B c t u b A$ gene was sequenced from one $\mathrm{Zox}^{\mathrm{S}}$ and six $\mathrm{Zox}^{\mathrm{R}}$ isolates. Sequence comparison revealed a substitution at position 198 from GAG to AAG resulting in replacement of glutamic acid by lysine (E198K) in three Zox ${ }^{R}$ isolates, and a substitution from GAG to GCG resulting in the replacement of glutamic acid by alanine (E198A) in two Zox ${ }^{\mathrm{R}}$ isolates. Interestingly, another point mutation was detected in the three $\operatorname{Zox}^{R}$ isolates with E198K point mutation, substitution from threonine to isoleucine at amino acid position 351 (T351I), which has also been detected previously by us in $B$. cinerea isolates from tomatoes (Adnan et al. 2018). Ten more zoxamide sensitive isolates were sequenced for further verification, and none of them possessed T351I point mutation, but E198A point mutation was detected from two isolates, indicating that the mutation of E198A was not responsible for zoxamide resistance. Point mutations E198K and T351I were detected together in all cases, but T351I point mutation never coexisted with E198A. One high resistant isolate possessed another substitution at position 200 resulting in the replacement of phenylalanine to tyrosine (F200Y) (Fig. 3a, b).

\section{Discussion}

B. cinerea is one of the limiting factors for the strawberry production in Hubei Province. The temperate climatic condition of Hubei Province is suitable for the pathogen to develop gray mold and cause serious yield 


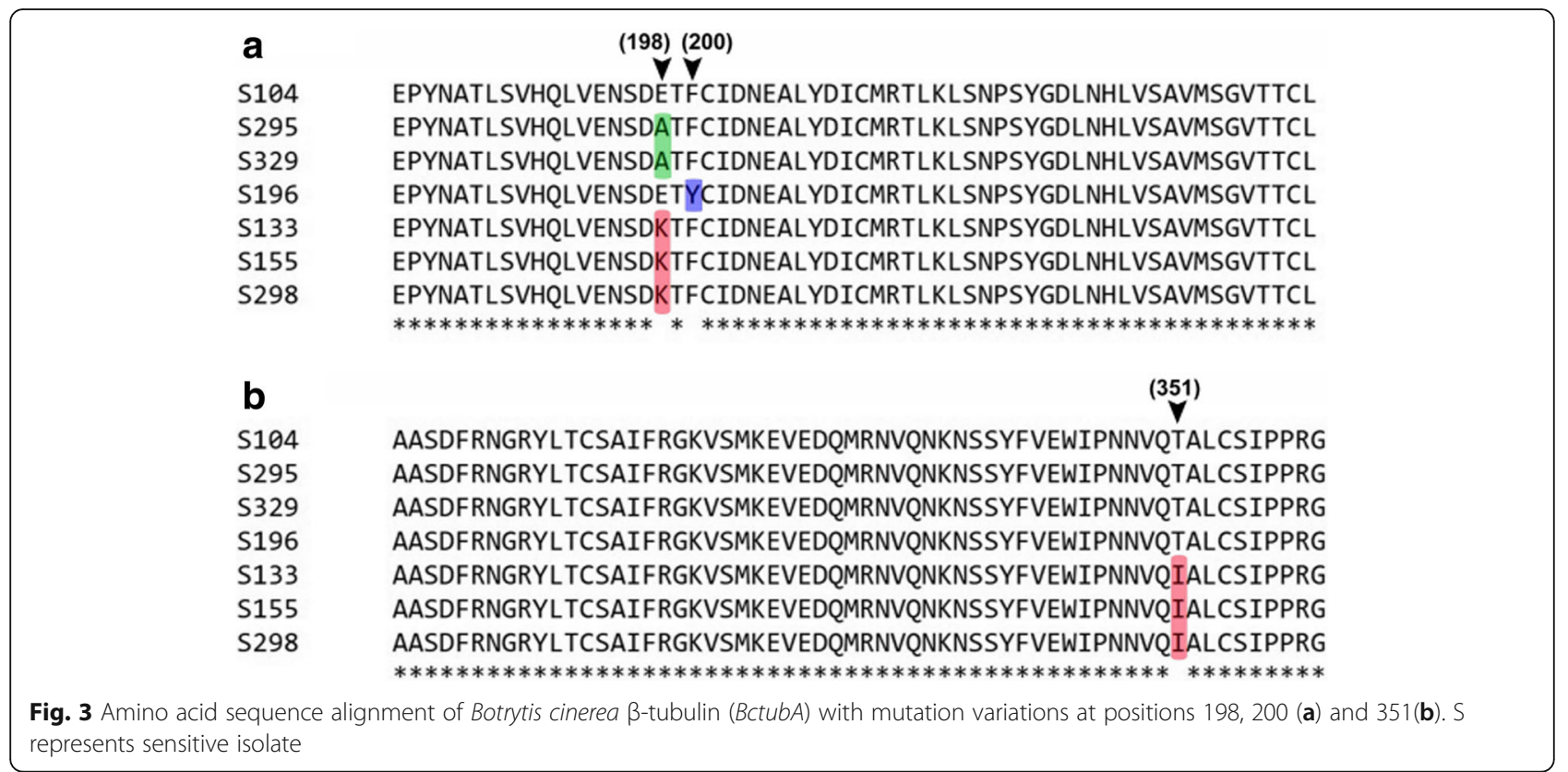

and quality losses. Currently, the essential measure to reduce such losses is the application of fungicides, however, sustained application of fungicides leads to selection pressure to develop fungicide resistance. Multiple fungicide resistance in B. cinerea field isolates was documented recently in Hubei Province (Fan et al. 2017). Similar trends of $B$. cinerea resistance in strawberry fields have been reported previously in Germany, Greece, USA and China (Amiri et al. 2013; Fernández-Ortuño et al. 2015; Konstantinou et al. 2015; Yin et al. 2015; Rupp et al. 2017) and also in other crops worldwide (Faretra and Pollastro 1991; Leroux et al. 2002; Sergeeva et al. 2002; Petsikos-Panayotarou et al. 2003; Moyano et al. 2004; Oshima et al. 2006; Sun et al. 2010; Korolev et al. 2011; Grabke et al. 2014; Cai et al. 2016; Liu et al. 2016). This study documents the occurrence of resistance in $B$. cinerea population from strawberries to procymidone and zoxamide. The results indicate that the development of various fungicide resistances in B. cinerea is common in strawberry greenhouse in Hubei Province, which is a real challenge for strawberry production. In order to solve this problem, there is an urgent need to develop effective resistance management strategies.

High frequencies of $B$. cinerea resistant isolates have been recorded not only to DCFs, MBCs but also to various classes of fungicides. The resistance frequency ranges from $18 \%$ to $86 \%$ in strawberry fields from all over the world including North and south Carolina, Florida, Greece, Germany and China (Amiri et al. 2013; Grabke et al. 2014; Fernández-Ortuño et al. 2015; Konstantinou et al. 2015; Yin et al. 2015; Rupp et al. 2017). High frequency of DCF resistance was documented in Hubei neighboring Province Henan (85\%) and also in Jiangsu Province (53\%) (Sun et al. 2010; Liu et al. 2016).
This study has witnessed low frequency of resistance as compared to previous studies, but there is no doubt that resistance levels will increase rapidly with the continuous use of DCF fungicides.

Among all the tested fitness parameters, no significant differences were observed except for osmotic sensitivity (procymidone) and sporulation (zoxamide). Otherwise, all $B$. cinerea resistant isolates showed similar fitness as sensitive ones, which is in line with previous studies (Moyano et al. 2004; Zhang et al. 2007; Sun et al. 2010; Liu et al. 2016; Rupp et al. 2017). Procymidone-resistant isolates were sensitive to fludioxonil (PPs) in this study, which confirms previous reports that no cross-resistance existed between DCFs and PPs in B. cinerea field isolates (Faretra and Pollastro 1993; Hilber et al. 1995; Leroux et al. 1999; Ziogas and Kalamarakis 2001; Vignutelli et al. 2002; Amiri et al. 2013; Li et al. 2014; Fernández-Ortuño et al. 2015; Yin et al. 2015). These results suggest fludioxonil is an excellent compound to manage $B$. cinerea populations resistant to DCFs.

Various mutations in the target gene $B c O s 1$ are responsible for resistance to DCFs (Ma et al. 2007; Grabke et al. 2014). One to several point mutations were detected in $B$. cinerea isolates with various resistance levels, but mutations at codon I365 were predominant (Oshima et al. 2006). In the current study, all isolates with low resistance showed variation in $\mathrm{I} 365 \mathrm{~S} / \mathrm{N}$ of $B c O s 1$ gene. This is confirmed by previous reports that low resistance was found to be related to single point mutations (I365N/S) in BcOs1 gene (Grabke et al. 2014). The low resistance of $B$. cinerea to DCFs was related to variations at codon $\mathrm{I} 365 \mathrm{~S} / \mathrm{N} / \mathrm{R}$ of $\mathrm{BcOs} 1$ (Leroux et al. 2002; Oshima et al. 2002; Cui et al. 2004; De Miccolis 
Angelini et al. 2007; Ma et al. 2007; Grabke et al. 2014). In the current study, all isolates with low resistance showed variation in $\mathrm{I} 365 \mathrm{~S} / \mathrm{N}$ of $\mathrm{BcOs} 1$ gene, which confirms previous reports that the mutation at this codon was responsible for low resistance. Moderate resistant isolates were associated with paired point mutations (Q369P, N373S) in BcOs1 gene (Grabke et al. 2014). Point mutations Q369P and N373S always appeared together in procymidone resistant isolates, consistent with the findings in Henan Province (Liu et al. 2016). In this study, it was also found that two mutations (Q369P, N373S) always appeared together. However, paired mutations Q369P and N373S were detected not only in moderately resistant (MR) isolates but also in low resistant isolates, as four LR isolates also possessed this pair of point mutations, which suggest that these mutations are not solely associated with MR phenotype.

Zoxamide is a benzamide fungicide having a similar mode of action as MBCs. Amino acid substitution in $B c t u b A$ gene are correlated with $\mathrm{MBCs}$ resistance in various pathogens including $B$. cinerea (Orbach et al. 1986; Fujimura et al. 1992; Koenraadt et al. 1992; Yarden and Katan 1993; Albertini et al. 1999; Dehne et al. 2004; Ma et al. 2007; Cabañas et al. 2009). The risk of resistance development to zoxamide is low while to MBCs is high for several pathogens (Smith 1988; Albertini et al. 1999; Krämer and Schirmer 2007; Cabañas et al. 2009; Sun et al. 2010; Malandrakis et al. 2011). In oomycetes, zoxamide lab-induced resistance has also rarely been reported except in Pythium sylvaticum and P. capsici (Martinez et al. 2003; Bi et al. 2011). A difference between zoxamide and MBCs is that zoxamide is used against diploid-oomycetes whereas $\mathrm{MBCs}$ are used against haploid true fungi (Bi et al. 2014). Zoxamide resistance selection risk was found to be low in laboratory experiments. Among eight B. cinerea sensitive isolates subjected to mycelial adaptation to zoxamide-amended medium, only one was mutated after ten transfers on zoxamide-containing media. The resulting two mutants showed significantly reduced growth and lack of sporulation (Cai et al. 2015). Molecular docking analysis showed the formation of two strong hydrogen bonds between side-chain of E198 and carbendazim, but zoxamide failed to form such interactions, which could explain why mutations at codon E198 have less effect on the sensitivity of zoxamide as compared to carbendazim. Authors proposed that difference in the binding-pocket of zoxamide and its target sites on BctubA protein make it different from MBCs (Cai et al. 2015). In inner Mongolia and Liaoning, $84 \%$ of $B$. cinerea isolates were found to be resistant to carbendazim (Cai et al. 2015). High frequency of $B$. cinerea resistant isolates to carbendazim was also detected in Hubei Province (Fan et al. 2017). In the current study, the frequency of zoxamide resistant isolates was observed in just 3\%, which is consistent with the previous reports. Our findings suggest that zoxamide still could be used to manage the resistance to MBCs in B. cinerea in some regions where resistance to zoxamide is still not developed.

The point mutations at codons 198 and 200 of the $B c t u b A$ gene are frequently reported (Malandrakis et al. 2011). It was previously documented that the replacement of glutamic acid at codon 198 by alanine, valine, glycine or lysine $(\mathrm{A} / \mathrm{V} / \mathrm{G} / \mathrm{K})$ is associated with high resistance levels to carbendazim (Fujimura et al. 1992; Koenraadt et al. 1992; Albertini et al. 1999; Cabañas et al. 2009; Malandrakis et al. 2011). The most predominant point mutation found in B. cinerea resistant isolates in Hubei Province to carbendazim was E198V (Fan et al. 2017). E198V mutation is not related with zoxamide resistance (Dehne et al. 2004; Malandrakis et al. 2011; Cai et al. 2015). In our findings, E198V point mutation was not detected among the zoxamide resistant isolates, indicating that zoxamide is a good alternative to control MBC resistant isolates with point mutation E198V.

In the majority of $B$. cinerea resistant isolates, mutation E198A was detected in BctubA gene and has been accounted for high resistance to MBCs (Banno et al. 2008; Li et al. 2014). E198A mutation was detected in isolates which were $\mathrm{HR}$ to MBCs but highly sensitive to zoxamide (Malandrakis et al. 2011). Increased sensitivity was observed towards zoxamide due to E198A mutation (Dehne et al. 2004; Malandrakis et al. 2011; Cai et al. 2015). In this study, E198A mutation was detected in two zoxamide resistant as well as two zoxamide sensitive isolates, indicating other mechanism instead of E198A conferred the resistance to zoxamide. A point mutation M233I was suggested to be the determinant of zoxamide resistance (Cai et al. 2015). A new point mutation T351I was detected in our study from three out of six isolates tested. Molecular docking analysis of BctubA gene with $\mathrm{MBCs}$ and zoxamide revealed that no direct interaction with E198 was detected even zoxamide was a component of the binding pocket (Cai et al. 2015). Interestingly, the point mutation T351I was only found in association with E198K in Zox ${ }^{R}$ isolates. We have previously reported for the first time T351I mutation in tomato isolates that was also detected in association with E198K mutation (Adnan et al. 2018). As no direct interaction between E198K and zoxamide was found, it is suggested that the T351I might be the cause of resistance. However, it could not be ruled out that both mutations of E198K and T351I interact and produce the resistance. To the best of our knowledge, this is the first report of the T351I mutation in field isolates of $B$. cinerea from strawberry. Mutation at codon 200 (F200Y) was detected in benzimidazole resistant isolates but with low frequency (Yarden and Katan 1993; Davidse and 
Ishii 1995; Walker et al. 2013; Rupp et al. 2016). The F200Y mutation has generally been found to confer the moderate resistance but also was responsible for high resistant phenotypes to MBCs (Yarden and Katan 1993; Davidse and Ishii 1995).

In our studies, we found F200Y mutation in one zoxamide high resistant isolate which is in line with previous literature. This mutation is also reported for the first time in zoxamide resistant field isolates of $B$. cinerea from strawberry. The decline in the frequency of strains with F200Y mutation has been observed when the application of fungicides mix (carbendazim + diethofencarb) was stopped (Billard et al. 2011). Such reason could be behind the low frequency of this mutation.

\section{Conclusions}

The risk of resistance selection in B. cinerea is a severe problem in strawberries in Hubei Province, China. According to our results, the resistance of $B$. cinerea to DCFs has occurred widely at most of the locations, and we can not rely on the use of DCFs separately to control this destructive disease. Although zoxamide has a similar mode of action as MBCs, the resistance frequency to zoxamide is much lower compared to that of MBCs in B. cinerea field isolates, indicating that zoxamide could be a component to control the $\mathrm{MBC}$ resistant isolates, especially for those containing the mutations E198A or E198V of the BctubA gene. Furthermore, integrated disease management strategies should be practiced followed, including besides the use of biological control and agricultural practices. For chemical control, fludioxonil could be a good option to be included in resistance management programs as no resistance was detected among the tested populations.

\section{Methods}

\section{Fungicides}

Procymidone $(50.0 \%$ active ingredient (a.i.); SUMILEX 50WP, Sumitomo-Chemical Co., Ltd. Japan), dimethachlon (96.0\% a.i.; Wenzhou-Pesticides Co., Ltd., Zhejiang, China), iprodione (50.0\% a.i.; Qingdao-Nintaus Pesticides Co., Ltd., Shandong, China), fludioxonil $(97.0 \%$ a.i.; Hubei-Jianyuan Chemical Co., Ltd.), technical-grade zoxamide ( $97.5 \%$ a.i.; Gowan-Company, LLC,Yuma, AZ, USA) and technical-grade carbendazim (92.0\% a.i.; Hubei-Jianyuan Chemical Co., Ltd.), were used in this study. Procymidone, dimethachlon, iprodione, and fludioxonil were each dissolved in acetone, while zoxamide and carbendazim were dissolved in DMSO (dimethyl sulfoxide) and lactic acid, respectively. Stock solutions were stored at $4{ }^{\circ} \mathrm{C}$ in the dark until used.

\section{Collection of $B$. cinerea isolates}

B. cinerea isolates $(\mathrm{n}=198)$ were obtained from commercial greenhouses in ten different locations of Hubei
Province during 2012-2013 (Additional file 1: Table S1). Isolates were isolated from diseased strawberry fruits or leaves, and single-spore isolation was performed as described in previous studies (Fernández-Ortuño et al. 2012). Isolates were stored at $-20^{\circ} \mathrm{C}$ on dried filter paper as described previously (Luo et al. 2002). Polymerase chain reaction (PCR) was used for identification of isolates with a primer pair Bc-f + Bc-r (5'-CAG GAA ACA CTT TTG GGG ATA/GAG GGA CAA GAA AAT CGA CTA A-3') (Fan et al. 2015).

\section{Monitoring of fungicide resistance in $B$. cinerea}

Discriminatory dose, a concentration of fungicide that completely inhibits mycelium growth of the sensitive isolates on agar plates, was used to distinguish $B$. cinerea resistant isolates from sensitive ones. A discriminatory dose of $5 \mu \mathrm{g} / \mathrm{mL}$ was used for both fungicides (procymidone and zoxamide) based upon previous studies (Moyano et al. 2004; Cai et al. 2015). Fungicides stock solutions were prepared in their particular solvents as mentioned above and amended to potato dextrose agar (PDA) medium to produce a final concentration of $5 \mu \mathrm{g} /$ $\mathrm{mL}$. The final concentration of acetone was limited to $0.1 \%(\mathrm{v} / \mathrm{v})$, and the controls always contained the same concentrations of solvents. A plug of $5 \mathrm{~mm}$ diameter was taken from the edge of 3-day-old colony growing on PDA at $23^{\circ} \mathrm{C}$ and transferred upside-down to the center of a PDA plate amended with the fungicide. The colony growth was observed visually after 3 days of incubation at $23^{\circ} \mathrm{C}$. For each fungicide, isolates grown successfully on fungicide-amended PDA and on control were considered as resistant, but isolates unable to grow on the amended PDA were termed as sensitive. The test was conducted twice with three replications for each isolate.

\section{Determination of fungicide sensitivity}

The sensitivity to procymidone was determined by evaluating the effective concentration resulting in inhibition of $50 \%$ growth $\left(\mathrm{EC}_{50}\right)$ values for $20 \mathrm{Pro}^{\mathrm{S}}$ and 27 Pro $^{\mathrm{R}}$ isolates. The sensitivity to zoxamide was determined by evaluating the $\mathrm{EC}_{50}$ values for $20 \mathrm{Zox}^{\mathrm{S}}$ and 6 Zox ${ }^{\mathrm{R}}$ isolates. All the isolates used to evaluate the $\mathrm{EC}_{50}$ values were randomly selected. Fungicides were dissolved in respective solvents as described before. The same concentration of solvents was used as a control. A primary test was conducted to estimate the range of effective concentrations $(0,0.001,0.01,0.1,1,10 \mu \mathrm{g} / \mathrm{mL})$. The final concentrations used for procymidone $\mathrm{EC}_{50}$ assay were $0,0.1,0.2,0.4,0.6,0.8,1 \mu \mathrm{g} / \mathrm{mL}$, and $0,0.02$, $0.06,0.12,0.36,0.72,1.4 \mu \mathrm{g} / \mathrm{mL}$ for zoxamide based upon preliminary tests. A plug of $5 \mathrm{~mm}$ diameter was taken from the edge of 3-day-old colony growing on PDA at $23^{\circ} \mathrm{C}$ and was placed upside-down to the middle of each PDA plate containing a series of fungicide 
concentrations. After 3 days incubation at $23^{\circ} \mathrm{C}$, the average colony diameter was evaluated by measuring colony growth in two perpendicular directions $(5 \mathrm{~mm}$ plug diameter was subtracted during calculations). The percentage of mycelium growth inhibition was calculated according to the formula, percent inhibition $=(1$-mean colony diameter on treated plates/mean colony diameter on non-treated plates) $\times 100 \%$. Linear regression of percent inhibitions in relation to control versus log transformed concentrations of procymidone and zoxamide was obtained. The $\mathrm{EC}_{50}$ values were calculated for all isolates using Data Processing System software (DPS 9.5). The Resistance Factor or RF value (the ratio of $\mathrm{EC}_{50}$ value for a resistant isolate relative to the mean $\mathrm{EC}_{50}$ value for sensitive isolates) was calculated, which indicates the sensitivity level of isolates. The experiment was performed twice with three replications. Average of results were calculated because no significant difference $(P>0.05)$ was observed in mycelium growth among the two experiments.

\section{Determination of the cross-resistance in $\operatorname{Pro}^{\mathrm{R}}$ and $\mathrm{Zox}^{\mathrm{R}}$ isolates}

The cross-resistance for procymidone and zoxamide resistant isolates to other fungicides was determined using a discriminatory dose test, which was performed according to previous literature ( $\mathrm{Li}$ et al. 2003; Alberoni et al. 2005). Pro ${ }^{R}$ isolates were tested for cross-resistance to iprodione, dimethachlon and fludioxonil, while $\mathrm{Zox}^{\mathrm{R}}$ isolates only to carbendazim. Based upon previous reports, the discriminatory concentrations were $1,5,5$, and $10 \mu \mathrm{g} / \mathrm{mL}$ for fludioxonil (Yin et al. 2015), dimethachlon (Ma et al. 2009), iprodione, and carbendazim (Bardas et al. 2010), respectively. Briefly, mycelial plug of $5 \mathrm{~mm}$ diameter was taken from the edge of 3-day-old colony and transferred to control and fungicide amended PDA. After 3 days of incubation at $23^{\circ} \mathrm{C}$, isolates showing normal colony growth on fungicide amended PDA were characterized as resistant, whereas sensitive isolates were those which failed to grow. The experiment was conducted twice with three replications.

\section{Evaluation of resistance stability}

To evaluate stability of procymidone and zoxamide resistant isolates, a method based on Kim and Xiao (2011) was used. Eight procymidone resistant (4LR, 4MR) and 6 zoxamide resistant isolates were randomly selected for the study. Briefly, the isolates were cultured on fungicide-free PDA and kept at $23^{\circ} \mathrm{C}$ in the dark. After every four days, cultures were shifted to fresh PDA plates. In this way, the isolates were cultured for ten generations. The sensitivity of 1 st and 10th generations to procymidone and zoxamide was determined using the mycelium growth assay as described before.

\section{Evaluation of the fitness of resistant isolates}

Mycelium growth, osmotic sensitivity (procymidone), virulence and sporulation were measured to evaluate the fitness of $\operatorname{Pro}^{\mathrm{R}}$ and $\mathrm{Zox}^{\mathrm{R}}$ isolates. Five sensitive isolates (4 $\mathrm{Pro}^{\mathrm{S}}$ and $1 \mathrm{Zox}^{\mathrm{S}}$ ) and 14 resistant isolates used in evaluation of resistance stability were tested.

Mycelium growth assay was conducted on fungicide-free PDA. Mycelial plugs were cut from the borders of 3 -day-old colony and transferred to the center of PDA plates. Four plates for each isolate were incubated at $23^{\circ} \mathrm{C}$ in the dark and colony growth diameter was measured at two perpendicular directions after $60 \mathrm{~h}$ of incubation.

Osmotic sensitivity was determined by evaluating the mycelium growth for each isolate on PDA amended with $\mathrm{NaCl}$. Briefly, mycelial plugs of $5 \mathrm{~mm}$ diameter from 3-day-old colony were placed on to PDA amended with $\mathrm{NaCl}$ at concentration of $8 \%$. The colony growth was measured at two perpendicular directions after 3 days of incubation at $23^{\circ} \mathrm{C}$. The percentage of inhibition for mycelium growth (PIMG) was calculated using the formula PIMG $=[(\mathrm{C}-\mathrm{N}) /(\mathrm{C}-5)] \times 100$, where $\mathrm{C}$ is the colony diameter of the non-treatment control, and $\mathrm{N}$ is that of the sodium chloride treatment.

The virulence and sporulation of isolates were determined on detached strawberry leaves as previously described (Fan et al. 2017). Fresh leaves were washed with $\mathrm{ddH}_{2} \mathrm{O}$ then dipped in $75 \%$ ethanol for $1 \mathrm{~min}$ followed by washing with $\mathrm{ddH}_{2} \mathrm{O}$ and retained on sterilized filter papers to dry. Leaves were placed on $3 \mathrm{~cm}$-diameter plastic rings in a plastic box with tissue paper soaked with sterile water at the bottom. Each leaf was punctured in the middle with a blood lancet (Yangzhou Shuangling Medical Appliance Co., Ltd., China) as conducted in a previous study (Fan et al. 2017). Mycelial plugs (5 mm diameter) from the margin of a 3-day-old colony were placed on top of the wounds. After inoculation, the boxes were enclosed with cling film to maintain humidity. Lesion diameter was measured with flexible plastic measuring tape after 4 days of incubation in the dark at $23^{\circ} \mathrm{C}$.

The inoculated strawberry leaves used for virulence test were further incubated at $23^{\circ} \mathrm{C}$ and under high humidity for an additional 10 days until enough sporulation occurred. Spores were removed by sterilized cotton buds and placed inside a $2 \mathrm{~mL}$ Eppendorf tube containing 1 $\mathrm{mL}$ of distilled water with $0.05 \%$ Tween 20 to keep spores separated. The sporulation for each isolate was counted microscopically using a hemocytometer.

Three leaves were used for each isolate. All experiments for fitness evaluation were conducted twice with three replications each.

\section{Evaluation of control efficacy of fungicides}

The control efficacy was assessed using the same isolates mentioned above. Before inoculation, the strawberry 
Table 3 Primers used in this study to amplify BcOs1 and BctubA gene fragments

\begin{tabular}{|c|c|c|c|}
\hline Primer & Sequence $\left(5^{\prime}-3^{\prime}\right)$ & Location in gene & Reference \\
\hline $\begin{array}{l}\text { BC-f (forward) } \\
\text { Bc-r (reverse) }\end{array}$ & $\begin{array}{l}\text { CAGGAAACACTITGGGGATA } \\
\text { GAGGGACAAGAAAATCGACTAA }\end{array}$ & Amplify 327 bp BcOs1 gene fragment of $B$. cinerea & (Fan et al. 2015) \\
\hline $\begin{array}{l}\text { BF1 (forward) } \\
\text { BR1 (reverse) }\end{array}$ & $\begin{array}{l}\text { TACCGATCGAAAAACCCAAC } \\
\text { TGGGCTGGTCTCTCAATCTT }\end{array}$ & Amplify 990 bp (95-1085) BcOs1 gene fragment of B. cinerea & (Ma et al. 2007) \\
\hline $\begin{array}{l}\text { BF2 (forward) } \\
\text { BR2 (reverse) }\end{array}$ & $\begin{array}{l}\text { CAACGTTATGGCACAAAATCTCA } \\
\text { AAGTTTCTGGCCATGGTGTTCA }\end{array}$ & Amplify $848 \mathrm{bp}$ (981-1829) BcOs1 gene fragment of B. cinerea & \\
\hline $\begin{array}{l}\text { P1 (forward) } \\
\text { P2 (reverse) }\end{array}$ & $\begin{array}{l}\text { ATGCGTGAGATTGTATGTATTTC } \\
\text { CTATTCCTCGCCCTCAATTG }\end{array}$ & Amplify 1765 bp $\beta$-tubulin gene fragment of $B$. cinerea & (Liu et al. 2010) \\
\hline $\begin{array}{l}\text { Bc365PM (forward) } \\
\text { Bc365PM (reverse) }\end{array}$ & $\begin{array}{l}\text { GAAAGCGAAGGCGTCCAG } \\
\text { GTCTCCCTITGCGACAGC }\end{array}$ & $\begin{array}{l}\text { Allele specific } P C R \text { primers to detect } \\
1365 S \text { point mutation in } B c O s 1 \text { gene }\end{array}$ & This study \\
\hline
\end{tabular}

leaves were prepared as indicated before. Procymidone and zoxamide were applied at the recommended field dose $\left(1.66 \mathrm{~g}\right.$ and $0.003 \mathrm{~g} / 500 \mathrm{~mL} \mathrm{ddH}_{2} \mathrm{O}$, respectively) onto strawberry leaves and left until air dry. Leaves sprayed with distilled water serves as control. Lesions diameter was measured with flexible plastic measuring tape after 5 days of incubation at $23^{\circ} \mathrm{C}$. The experiment was performed twice with three leaves per treatment. Finally, the following equation was used to calculate control efficacy: Disease control efficacy $=($ Lesion growth of control - lesion growth of treatment) / lesion growth of control $\times 100 \%$.

\section{Amplification and sequencing of $B c O s 1$ and $B c t u b A$ genes} Mycelia were collected from 3-day-old colonies of selected isolates on PDA incubated at $23^{\circ} \mathrm{C}$. DNA was extracted and purified according to the method of Chi et al. (2009). Based on the DNA sequence of $\mathrm{BcOs} 1$ gene (Gen-Bank accession number AF396827), two primer pairs (BR1 + BF1 and BR2 + BF2) were used to amplify two fragments (95-1085 bp, 981-1829 bp) of BcOs1 (Table 3). To amplify a fragment of $\mathrm{BcOs} 1$ carrying I365S single point mutation, the specific PCR primer pair (Bc365PM-F, Bc365PM-R) designed by using Primer Premier V5 was used for remaining Pro $^{\mathrm{R}}$ isolates (Table 3$)$. The PCR conditions were: $94{ }^{\circ} \mathrm{C}$ preheating for $2 \mathrm{~min}$, followed by 32 cycles of denaturation at $94^{\circ} \mathrm{C}$ for $30 \mathrm{~s}$, annealing at $58.3^{\circ} \mathrm{C}$ for BF2 + BR2 or $57^{\circ} \mathrm{C}$ for BF1 + BR1, Bc365PM-F $+\mathrm{Bc} 365 \mathrm{PM}-\mathrm{R}$ for $30 \mathrm{~s}$, and extension at $72^{\circ} \mathrm{C}$ for $70 \mathrm{~s}$, with 5 min of final extension at $72{ }^{\circ} \mathrm{C}$.

A primer pair P1-P2 was used to amplify the $1765 \mathrm{bp}$ fragment of $B c t u b A$ gene (Table 3 ). PCR reaction volume $(50 \mu \mathrm{L})$ included $2 \mu \mathrm{L}$ of fungal genomic DNA (50 ng), $1 \mu \mathrm{L}$ of each primer $(0.2 \mu \mathrm{M}), 21 \mu \mathrm{L} \mathrm{ddH}_{2} \mathrm{O}$ and $25 \mu \mathrm{L}$ $2 \times$ Taq PCR Mix (AidLab Biotech, China). The PCR conditions used were: $94{ }^{\circ} \mathrm{C}$ preheating for $5 \mathrm{~min}$, followed by 35 cycles of denaturation at $94{ }^{\circ} \mathrm{C}$ for $1 \mathrm{~min}$, annealing at $63^{\circ} \mathrm{C}$ for $1 \mathrm{~min}$, and extension at $72{ }^{\circ} \mathrm{C}$ for $90 \mathrm{~s}$, with $10 \mathrm{~min}$ of final extension at $72^{\circ} \mathrm{C}$ and a holding temperature of $4{ }^{\circ} \mathrm{C}$.
Amplified PCR products were separated by electrophoresis in a 1.5\% agarose gel in Tris-acetate-EDTA (Oshima et al. 2006) buffer, stained with EB (ethidium bromide) and photographed. The amplified fragment was purified by using a UNIQ gel extraction kit (EasyPure Quick Gel Extraction Kit, TransGen Biotech Co., Beijing, China), and then sequenced at Wuhan Tianyi Huiyuan Biotechnology Co., Ltd. BioEdit Sequence Alignment Editor Version 7.1.3.0 and ClustalW was used for the sequence analysis.

\section{Additional file}

Additional file 1: Table S1. Number of Botrytis cinerea isolates collected from strawberry greenhouses at ten locations in Hubei Province, China. (DOC 20 kb)

\section{Abbreviations}

APs: Anilinopyrimidines;; BcOs 1: Botrytis cinerea two-component histidine kinase gene; BctubA: Beta-tubulin gene; DCFs: Dicarboximides; E198A, V

K: Substitutions from glutamic acid to alanine, valine, lysine at codon 198 of BctubA; $\mathrm{EC}_{50}$ : Effective concentration at which mycelium growth is inhibited by 50\%; F200Y: Mutation at codon 200 of BctubA substituting phenylalanine by tyrosine; 1365N/S, Q369P, N373S: Substitutions from isoleucine to asparagine/serine at codon 365, glutamine to proline at codon 369, asparagine to serine at codon 373; LR, MR, HR isolates: Low, moderate, high resistant isolates; MBCs: Methyl Benzimidazole Carbamates or Benzimidazole fungicides; NPCs: N-phenylcarbamates; PDA: Potato dextrose agar; PPs: Phenylpyrroles; Pro ${ }^{S}$ and Pro ${ }^{R}$ : Procymidone sensitive and resistant; Qols: Quinone outside inhibitors; SDHIs: Succinate dehydrogenase inhibitors; T351l: Mutation at codon 351 of BctubA substituting threonine by isoleucine

\section{Acknowledgements}

We are grateful to Miss Na Li, a former graduate student of Professor Guoqing Li for providing us the isolates used in this study. Special gratitude is expressed towards Professor Xili Liu from Northwest A\&F University for providing the fungicide zoxamide.

\section{Funding}

This work is supported by the Special Fund for Agro-scientific Research in the Public Interest (Nos. 201303025 and 201303023).

Availability of data and materials

The datasets used and/or analyzed during the current study are available from the corresponding author on reasonable request. 


\section{Authors' contributions}

MA, MSH and C-XL designed the research; MA and MSH performed the research; MA, MH, G-QL and C-XL wrote the manuscript, all authors read and approved the final manuscript.

\section{Ethics approval and consent to participate}

Not applicable.

\section{Consent for publication}

Not applicable

\section{Competing interests}

The authors declare that they have no competing interests.

\section{Author details}

${ }^{1}$ Key Lab of Horticultural Plant Biology, Ministry of Education, and College of Plant Science and Technology, Huazhong Agricultural University, Wuhan 430070, China. ${ }^{2}$ Pesticides Department, Faculty of Agriculture, Mansoura University, Mansoura 35516, Egypt. ${ }^{3}$ University of Kaiserslautern, Department of Biology, 67653 Kaiserslautern, Germany. ${ }^{4}$ College of Plant Science and Technology and the Key Lab of Crop Disease Monitoring \& Safety Control in Hubei Province, Huazhong Agricultural University, Wuhan 430070, China.

Received: 25 January 2019 Accepted: 17 April 2019

Published online: 20 May 2019

\section{References}

Adnan M, Hamada M, Li G, Luo C. Detection and molecular characterization of resistance to the dicarboximide and benzamide fungicides in Botrytis cinerea from tomato in Hubei Province, China. Plant Dis. 2018;102:1299-306.

Alberoni G, Collina M, Pancaldi D, Brunelli A. Resistance to dicarboximide fungicides in Stemphylium vesicarium of Italian pear orchards. Eur J Plant Pathol. 2005;113:211-9.

Albertini C, Gredt M, Leroux P. Mutations of the $\beta$-tubulin gene associated with different phenotypes of benzimidazole resistance in the cereal eyespot fungi Tapesia yallundae and Tapesia acuformis. Pestic Biochem Physiol. 1999:64:17-31.

Amiri A, Heath S, Peres N. Phenotypic characterization of multifungicide resistance in Botrytis cinerea isolates from strawberry fields in Florida. Plant Dis. 2013;97:393-401.

Banno S, Fukumori F, Ichiishi A, Okada K, Uekusa H, Kimura M, et al. Genotyping of benzimidazole-resistant and dicarboximide-resistant mutations in Botrytis cinerea using real-time polymerase chain reaction assays. Phytopathology. 2008:98:397-404

Bardas GA, Veloukas T, Koutita O, Karaoglanidis GS. Multiple resistance of Botrytis cinerea from kiwifruit to SDHIs, Qols and fungicides of other chemical groups. Pest Manag Sci. 2010;66:967-73.

Bi Y, Chen L, Cai M, Zhu S, Pang Z, Liu X. Two non-target recessive genes confer resistance to the anti-oomycete microtubule inhibitor zoxamide in Phytophthora capsici. PLoS One. 2014;9:e89336.

Bi Y, Cui X, Lu X, Cai M, Liu X, Hao JJ. Baseline sensitivity of natural population and resistance of mutants in Phytophthora capsici to zoxamide. Phytopathology. 2011;101:1104-11.

Billard A, Fillinger S, Leroux P, Bach J, Lanen C, Lachaise $H$, et al. Fenhexamid resistance in the Botrytis species complex, responsible for grey mould disease. In: Thajuddin N, editor. Fungicides-Beneficial and Harmful Aspects. Rijeka: InTech; 2011. p. 61-78.

Braun P, Sutton J. Inoculum sources of Botrytis cinerea in fruit rot of strawberries in Ontario. Can J Plant Pathol. 1987:9:1-5.

Brent KJ, Hollomon DW. Fungicide resistance: The assessment of risk. Brussels: FRAC; 2007.

Cabañas R, Castellá G, Abarca ML, Bragulat MR, Cabañes FJ. Thiabendazole resistance and mutations in the $\beta$-tubulin gene of Penicillium expansum strains isolated from apples and pears with blue mold decay. FEMS Microbiol Lett. 2009;297:189-95.

Cai M, Lin D, Chen L, Bi Y, Xiao L, Liu XL. M233I mutation in the $\beta$-tubulin of Botrytis cinerea confers resistance to zoxamide. Sci Rep. 2015;5:16881.

Cai M, Miao J, Song X, Lin D, Bi Y, Chen L, et al. C2395 mutation in the $\beta$-tubulin of Phytophthora sojae confers resistance to zoxamide. Front Microbiol. 2016;7:762.

Chi M-H, Park S-Y, Lee Y-H. A quick and safe method for fungal DNA extraction. Plant Pathol J. 2009;25:108-11.
Cui W, Beever RE, Parkes SL, Templeton MD. Evolution of an osmosensing histidine kinase in field strains of Botryotinia fuckeliana (Botrytis cinerea) in response to dicarboximide fungicide usage. Phytopathology. 2004;94:1129-35.

Davidse LC, Ishii H. Biochemical and molecular aspects of the mechanisms of action of benzimidazoles, $\mathrm{N}$-phenylcarbamates and $\mathrm{N}$ phenylformamidoximes and the mechanisms of resistance to these compounds in fungi. In: Lyr H, editor. Modern selective fungicidesproperties. Jena: Gustav Fisher Verlag; 1995. p. 305-22.

De Miccolis Angelini RM, Rotolo C, Habib W, Pollastro S, Faretra F. Single nucleotide polymorphisms (SNPs) in Botryotinia fuckeliana genes involved in fungicide resistance. Proceedding of the 14th international Botrytis symposium. Cape Town; 2007. p. 21-6.

Dean R, Van Kan JA, Pretorius ZA, Hammond-Kosack KE, Di Pietro A, Spanu PD, et al. The top 10 fungal pathogens in molecular plant pathology. Mol Plant Pathol. 2012:13:414-30.

Dehne H, Gisi U, Kuck K, Russell P, Lyr H. Modern fungicides and antifungal compounds IV. Proceeding of the 14th international Reinhardsbrunn symposium British crop protection council, Friedrichroda; 2004. p. 368.

Diolez A, Marches F, Fortini D, Brygoo Y. Boty, a long-terminal-repeat retroelement in the phytopathogenic fungus Botrytis cinerea. Appl Environ Microbiol. 1995:61:103-8.

Elad Y, Williamson B, Tudzynski P, Delen N. Botrytis: biology, pathology and control. Dordrecht: Springer; 2004

Elad Y, Yunis H, Katan T. Multiple fungicide resistance to benzimidazoles, dicarboximides and diethofencarb in field isolates of Botrytis cinerea in Israel. Plant Pathol. 1992;41:41-6.

Ellis M, Grove G. Fruit rots cause losses in Ohio strawberries (Botrytis cinerea, Phytophthora cactorum). In: Ohio agricultural Research and Development Center. USA: Wooster; 1982

Fan F, Hamada M, Li N, Li G, Luo C. Multiple fungicide resistance in Botrytis cinerea from greenhouse strawberries in Hubei province, China. Plant Dis. 2017:101:601-6.

Fan X, Zhang J, Yang L, Wu M, Chen W, Li G. Development of PCR-based assays for detecting and differentiating three species of Botrytis infecting broad bean. Plant Dis. 2015;99:691-8.

Faretra F, Pollastro S. Genetic basis of resistance to benzimidazole and dicarboximide fungicides in Botryotinia fuckeliana (Botrytis cinerea). Mycol Res. 1991;95:943-51.

Faretra F, Pollastro S. Genetics of sexual compatibility and resistance to benzimidazole and dicarboximide fungicides in isolates of Botryotinia fuckeliana (Botrytis cinerea) from nine countries. Plant Pathol. 1993;42:48-57.

Fernández-Ortuño D, Chen F, Schnabel G. Resistance to pyraclostrobin and boscalid in Botrytis cinerea isolates from strawberry fields in the Carolinas. Plant Dis. 2012;96:1198-203.

Fernández-Ortuño D, Grabke A, Li X, Schnabel G. Independent emergence of resistance to seven chemical classes of fungicides in Botrytis cinerea. Phytopathology. 2015;105:424-32.

Fujimura M, Kamakura T, Inoue H, Inoue S, Yamaguchi I. Sensitivity of Neurospora crassa to benzimidazoles and N-phenylcarbamates: effect of amino acid substitutions at position 198 in $\beta$-tubulin. Pestic Biochem Physiol. 1992;44:165-73.

Grabke A, Fernández-Ortuño D, Amiri A, Li X, Peres NA, Smith P, et al. Characterization of iprodione resistance in Botrytis cinerea from strawberry and blackberry. Phytopathology. 2014:104:396-402.

Hilber UW, Schwinn FJ, Schüepp H. Comparative resistance patterns of fludioxonil and vinclozolin in Botryotinia fuckeliana. J Phytopathol. 1995;143:423-8.

Kim YK, Xiao CL. Stability and fitness of pyraclostrobin and boscalid resistant phenotypes in field isolates of Botrytis cinerea from apple. Phytopathology. 2011;101:1385-91.

Koenraadt $\mathrm{H}$, Somerville SC, Jones AL. Characterization of mutations in the betatubulin gene of benomyl-resistant field strains of Venturia inaequalis and other plant pathogenic fungi. Phytopathology. 1992;82:1348-54.

Konstantinou S, Veloukas T, Leroch M, Menexes G, Hahn M, Karaoglanidis G. Population structure, fungicide resistance profile, and $\operatorname{s} \operatorname{sh} B$ mutation frequency of Botrytis cinerea from strawberry and greenhouse-grown tomato in Greece. Plant Dis. 2015;99:240-8.

Korolev KS, Xavier JB, Nelson DR, Foster KR. A quantitative test of population genetics using spatiogenetic patterns in bacterial colonies. Am Nat. 2011;178:538-52.

Krämer W, Schirmer U. Modern crop protection compounds. 2nd ed. Weinheim: WILEY-VCH Verlag GmbH \& Co. KGaA; 2007.

Legard D, Chandler C. Evaluation of fungicides to control Botrytis fruit rot of strawberry. F\&N Tests. 1998;53:121. 
Leroux P, Chapeland F, Desbrosses D, Gredt M. Patterns of cross-resistance to fungicides in Botryotinia fuckeliana (Botrytis cinerea) isolates from French vineyards. Crop Prot. 1999;18:687-97.

Leroux P, Fritz R, Debieu D, Albertini C, Lanen C, Bach J, et al. Mechanisms of resistance to fungicides in field strains of Botrytis cinerea. Pest Manag Sci. 2002;58:876-88

Li HX, Lu YJ, Zhou MG, Wang XF. Mutation in $\beta$-tubulin of Sclerotinia sclerotiorum conferring resistance to carbendazim in rapeseed field isolates. Chin J Oil Crop Sci. 2003;2:56-60 in Chinese.

Li X, Fernández-Ortuño D, Chen S, Grabke A, Luo C-X, Bridges WC, et al. Locationspecific fungicide resistance profiles and evidence for stepwise accumulation of resistance in Botrytis cinerea. Plant Dis. 2014;98:1066-74.

Liu S, Che Z, Chen G. Multiple-fungicide resistance to carbendazim, diethofencarb, procymidone, and pyrimethanil in field isolates of Botrytis cinerea from tomato in Henan Province, China. Crop Prot. 2016;84:56-61.

Liu SM, Chen Y, Yu JJ, Chen CJ, Wang JX, Zhou MG. Transfer of the beta-tubulin gene of Botrytis cinerea with resistance to carbendazim into Fusarium graminearum. Pest Manag Sci. 2010;66:482-9.

Luo C-X, Hanamura H, Sezaki H, Kusaba M, Yaegashi H. Relationship between avirulence genes of the same family in rice blast fungus Magnaporthe grisea. J Gen Plant Pathol. 2002:68:300-6.

Ma H-X, Chen Y, Wang J-X, Yu W-Y, Tang Z-H, Chen C-J, et al. Activity of carbendazim, dimethachlon, iprodione, procymidone and boscalid against Sclerotinia stem rot in Jiangsu Province of China. Phytoparasitica. 2009;37:421.

Ma Z, Yan L, Luo Y, Michailides TJ. Sequence variation in the two-component histidine kinase gene of Botrytis cinerea associated with resistance to dicarboximide fungicides. Pestic Biochem Physiol. 2007;88:300-6.

Malandrakis A, Markoglou A, Ziogas B. Molecular characterization of benzimidazoleresistant $B$. cinerea field isolates with reduced or enhanced sensitivity to zoxamide and diethofencarb. Pestic Biochem Physiol. 2011;99:118-24.

Malathrakis N. Studies on gray mold (Botrytis cinerea) of vegetables grown under plastics. Phytopathol Mediterr. 1979;19:70.

Martinez F, Blancard D, Lecomte P, Levis C, Dubos B, Fermaud M. Phenotypic differences between vacuma and transposa subpopulations of Botrytis cinerea. Eur J Plant Pathol. 2003;109:479-88.

Moorman GW, Lease RJ. Benzimidazole- and dicarboximide-resistant Botrytis cinerea from Pennsylvania greenhouses. Plant Dis. 1992;76:477-80.

Moyano C, Gómez V, Melgarejo P. Resistance to pyrimethanil and othe fungicides in Botrytis cinerea populations collected on vegetable crops in Spain. J Phytopathol. 2004;152:484-90.

Neumann GL. Pyrimethanil: a new fungicide. Proceeding of the Brighton crop protection conference, pests and diseases. Farnham-UK: Brit Crop Prot Coun; 1992. p. 395-402

Orbach MJ, Porro EB, Yanofsky C. Cloning and characterization of the gene for beta-tubulin from a benomyl-resistant mutant of Neurospora crassa and its use as a dominant selectable marker. Mol Cell Biol. 1986;6:2452-61.

Oshima M, Banno S, Okada K, Takeuchi T, Kimura M, Ichiishi A, et al. Survey of mutations of a histidine kinase gene BCOS1 in dicarboximide-resistant field isolates of Botrytis cinerea. J Gen Plant Pathol. 2006;72:65-73.

Oshima M, Fujimura M, Banno S, Hashimoto C, Motoyama T, Ichiishi A, et al. A point mutation in the two-component histidine kinase BCOS-1 gene confers dicarboximide resistance in field isolates of Botrytis cinerea. Phytopathology. 2002;92:75-80.

Pappas AC. Evolution of fungicide resistance in Botrytis cinerea in protected crops in Greece. Crop Prot. 1997:16:257-63.

Petsikos-Panayotarou N, Markellou E, Kalamarakis AE, Kyriakopoulou D, Malathrakis NE. In vitro and in vivo activity of cyprodinil and pyrimethanil on Botrytis cinerea isolates resistant to other botryticides and selection for resistance to pyrimethanil in a greenhouse population in Greece. Eur J Plant Pathol. 2003;109:173-82

Rupp S, Weber RW, Rieger D, Detzel P, Hahn M. Spread of Botrytis cinerea strains with multiple fungicide resistance in German horticulture. Front Microbiol. 2017;7:2075.

Rupp S, Weber RWS, Rieger D, Detzel P, Hahn M. Spread of Botrytis cinerea strains with multiple fungicide resistance in German horticulture. Front Microbiol. 2016;7:2075.

Sergeeva V, Nair NG, Verdanega JR, Shen C, Barchia I, Spooner-Hart R. First report of anilinopyrimidine-resistant phenotypes in Botrytis cinerea on grapevines in Australia. Aus Plant Pathol. 2002;31:299-300.

Smith CM. History of benzimidazole use and resistance. In: Delp CJ, editor. Fungicide resistance in North America. St Paul, MN: APS Press; 1988. p. 23-4.
Stehmann C, Waard MAD. Sensitivity of populations of Botrytis cinerea to triazoles, benomyl and vinclozolin. Eur J Plant Pathol. 1996;102:171-80.

Sun HY, Wang HC, Yu C, Li HX, Chen CJ, Zhou MG. Multiple resistance of Botrytis cinerea from vegetable crops to carbendazim, diethofencarb, procymidone, and pyrimethanil in China. Plant Dis. 2010;94:551-6.

Vignutelli A, Hilber-Bodmer M, Hilber UW. Genetic analysis of resistance to the phenylpyrrole fludioxonil and the dicarboximide vinclozolin in Botryotinia fuckeliana (Botrytis cinerea). Mycol Res. 2002;106:329-35.

Walker AS, Micoud A, Rémuson F, Grosman J, Gredt M, Leroux P. French vineyards provide information that opens ways for effective resistance management of Botrytis cinerea (grey mould). Pest Manag Sci. 2013;69:66778.

Williamson B, Tudzynski B, Tudzynski P, Kan JALV. Botrytis cinerea: the cause of grey mould disease. Mol Plant Pathol. 2007:8:561-80.

Xiang FY, Han YC, Zeng XG, Gu YC, Chen FY. The development situation and prospect of strawberry industry in western Hubei mountain districts. Hubei Agric Sci. 2015;54:5930 in Chinese.

Yarden O, Katan T. Mutations leading to substitutions at amino acids 198 and 200 of beta-tubulin that correlate with benomyl-resistance phenotypes of field strains of Botrytis cinerea. Phytopathology. 1993;83:1478-83.

Yin D, Chen X, Hamada MS, Yu M, Yin Y, Ma Z. Multiple resistance to Qols and other classes of fungicides in Botrytis cinerea populations from strawberry in Zhejiang Province, China. Eur J Plant Pathol. 2015;141:169-77.

Young DH, Slawecki RA. Mode of action of zoxamide ( $\mathrm{RH}-7281)$, a new oomycete fungicide. Pestic Biochem Physiol. 2001;69:100-11.

Young DH, Spiewak SL, Slawecki RA. Laboratory studies to assess the risk of development of resistance to zoxamide. Pest Manag Sci. 2001;57:1081-7.

Zhang H, Wang L, Dong Y, Jiang S, Cao J, Meng R. Postharvest biological control of gray mold decay of strawberry with Rhodotorula glutinis. Biol Control. 2007:40:287-92.

Ziogas BN, Kalamarakis AE. Phenylpyrrole fungicides: mitotic instability in Aspergillus nidulans and resistance in Botrytis cinerea. J Phytopathol. 2001;149: 301-8.

\section{Ready to submit your research? Choose BMC and benefit from:}

- fast, convenient online submission

- thorough peer review by experienced researchers in your field

- rapid publication on acceptance

- support for research data, including large and complex data types

- gold Open Access which fosters wider collaboration and increased citations

- maximum visibility for your research: over $100 \mathrm{M}$ website views per year

At $\mathrm{BMC}$, research is always in progress.

Learn more biomedcentral.com/submissions 